\title{
Bohumil Hrabal and the Poetics of Aging
}

\author{
$\dddot{\bullet}$ \\ Daniel Just
}

\section{Aging in Modern Fictions}

Modern literary fictions offer a wide range of representations of aging, from vitalism to nihilism. For example, in Doris Lessing's "The Grandmothers" the two female protagonists retain their vitality and zest for life as they grow older. In Gabriel García Márquez's The General in the Labyrinth the elderly Simón Bolívar has lost most of his vitality, but he still reflects on his life with calm and curiosity, unlike Hagar Shipley in Margaret Laurence's Stone Angel, who rages against growing old. A lightly ironic attitude to aging is a further step away from vitalism. In Thomas Mann's Death in Venice the aging writer Aschenbach interprets Plato's Phaedrus-and misinterprets, as Helen Small demonstrates (35-52) -in an attempt to manage his infatuation with the young boy Tadzio, with the narrator incorporating Aschenbach's interpretations into his story to an ironic effect which foreshadows Aschenbach's realization that he cannot live up to Plato's ideal. Gustave Flaubert's Bouvard and Pécuchet is more openly satirical about aging by depicting an assortment of outlandish occupations in which two retired friends engage in order to stave off the monotony of old age. The protagonist in J. M. Coetzee's Disgrace has no illusions about this looming monotony, and yet even he tries to delay it when he has a chance. Another step away from vitalism is the theme of wasted opportunities: a missed opportunity that is not recognized as such (e.g., John Marcher in Henry James's The Beast in the Jungle), 
one that is recognized (e.g., James Stevens in Kazuo Ishiguro's The Remains of the Day), and an overpowering feeling that one has squandered one's entire life (e.g., Ivan Ilych in Tolstoy's The Death of Ivan Ilych). Georgi Gospodinov's The Physics of Sorrow is a variation on this theme, but no longer with any trace of vitalism. Gospodinov's autobiographical protagonist-narrator views aging melancholically, as a growing realization that human existence is intrinsically hollow: "longing for something lost or that had never taken place" (75). In Thomas Bernhard's memoir Gathering Evidence, as well as in his later novels-for example, Reger in Old Masters and Franz-Josef Murau in Extinction - the hollowness of existence loses its melancholic undertone and becomes nihilistic: "Nothing mattered-that was the truth of it. It was a question of age. Nothing mattered" (212). Louis-Ferdinand Céline's novels present a similarly nihilistic attitude toward aging with the added ingredient of bitterness and fury: “... at a certain age nothing means anything..." (Rigadoon 200); "smile and grimaces, victors and vanquished, same cauldron! ... what you want at the end of your life is not to see them any more, not to talk about anything, you've seen enough" (North 230).

What all these different representations of aging in modern fictions have in common is that their narrative operation renders them irreducible to statements and propositions. Even straightforward declarations, such as Céline's, are inseparable from literary poetics that shapes their meaning. In Céline's case, part of this poetics is his explosive and at times rambling style interspersed with exclamation points, ellipses, and self-mockery: "More of my rancor!... you'll forgive me for being a little soft in the head... but not if it gets so bad that I bore you... me and my three dots... a little discretion!... my supposedly original style!..." (Castle to Castle 338). But perhaps even more important than style when it comes to rendering aging in modern fictions is the creative use of anachrony. Presentation of material out of chronological order takes on various forms in modern narratives, but three main tendencies stand out. The first is the prominence of ellipses, prolepses, and analepses. These devices break chronological sequence by momentarily stepping out of it. Marcel Proust's In Search for Lost Time is an exemplary case. Proust frequently deploys prolepses and analepses to enable reader's easier orientation in the long story of the protagonist-narrator's development from his childhood to older age. But these devices have the opposite effect as well: they complicate what the text communicates and add layers of meaning to it. While at the initial stages of reading In Search for Lost Time prolepses and 
analepses guide the reader through the narrative and facilitate a better sense of where it is going, at the same time they problematize what the narrator tells us at each point. As Joshua Landy points out, by the time the narrator reaches the last volume, in which he brings most key events from previous volumes to significance, it is not only the hero who has changed, but also the narrator (33). The last volume renders some of narrator's earlier proleptic statements about aging invalid, for they were made by his younger version. Proust's intricate use of anachrony encourages readers' active involvement with the text and reconstruction of what it offers with respect to how it represents aging.

The second main implementation of anachrony in modern fictions is the narrative structure of simultaneity. In Virginia Woolf's Mrs. Dalloway the narrator tells her story in a non-chronological fashion, as an interplay between past (memory) and present (perception) that is taking place in the protagonist's mind. Penelope Lively uses the same strategy in Moon Tiger, in which it becomes a narrative counterpart to the elderly protagonist's understanding of time "not as a sequence just a single event without beginning or end in any proper sense simply a continuity spiked by moments of intensity that ring in the head still" (196). In Moon Tiger the narrative form of simultaneity represents aging as continuity rather than progression from one stage to another: "an old woman is not someone who has moved into a distinct stage and category of life, but merely a woman who is old" (King 120).

The third implementation of anachrony is in the form of chronological displacements, such as withheld information and play with gaps. For instance, in Milan Kundera's The Unbearable Lightness of Being the third-person narrator is suppressive rather than open and direct. He does not state his message about aging in a straightforward, didactic manner, but more obliquely. What in the story world is the hero's slow arrival at his realization that he can lead a satisfying life without a conqueror-like attitude is narrated in the form of summary, to which the sequel adds new facts and angles in passages that favor explaining over narrating, and narrator's commentary and self-focusing over focalization through characters. This technique, too, stimulates reader's active approach to the text. Like Proust's ellipses, prolepses, and analepses, and Woolf and Lively's narrative structure of simultaneity, Kundera's narrator, who suppresses information, retells the story from several points of view, and foregrounds his own opinions, engages the reader in critical dialogue with what the text communicates about aging.

As these examples demonstrate, representations of aging in modern fictions cannot be reduced to statements and used as evidence or 
illustration of some deeper truths. These representations are inextricable from formal and aesthetic aspects of the text. They involve a creative process of poetics whereby writers depict aging. When this process is carried out with an awareness on the side of the writer of both literary tradition and society at large, a literary work creates a poetics of aging that can influence how we think about aging. The concept of "poetics of aging" was coined by Thomas Falkner in his study of ancient Greek accounts of old age in texts by Homer, Sappho, and Sophocles. Falkner examines elements in these texts that reflect dominant views on aging and their expression in ancient Greek society and literature, but he also identifies those that subvert these views. More recently, Nicola Carpentieri applied this concept in his analysis of the medieval Sicilian Arab poet Ibn Hamdīs. Carpentieri argues that Ibn Hamdīs adheres to certain figures from a codified aesthetics of Islamic poetry to enhance his poems' conceptual unity, while at the same time creatively modifying some of the canonical motifs of growing older, a dual tactic which Carpentieri regards as an outcome of, on the one hand, the poet's anticipation of the end of Islam in Europe, and, on the other, his determination to revitalize Islamic culture and prevent its collapse. For both Falkner and Carpentieri, poetics of aging is a writer's individual, creative, and innovative take on prevailing conceptions of aging in literature and society that has the potential to affect and shape our understanding of what it means to grow older.

The concept of poetics of aging has inspired scholars outside literary studies as well, particularly in the field of narrative gerontology. Gerontologists have modified its meaning to describe attempts by aging individuals who wish to age actively rather than passively, by deliberately emplotting and reemplotting stories of their lives. The cornerstone of the idea of active aging is R. N. Butler's argument that aging leads to "life review": "a naturally occurring universal mental process characterized by the progressive return to consciousness of past experiences and, particularly, the resurrection of unresolved conflicts; simultaneously, and normally, these experiences and conflicts can be surveyed and reintegrated" (66). According to the psychoanalyst Danielle Quinodoz, this reintegration responds to our pressing need to take stock of our internal life-history and give meaning to it as a whole (1-5). Once this happens repeatedly and purposefully, as Elizabeth McKim and William L. Randall propose, we are dynamically "storying" and "restorying" our life experiences ("From Psychology to Poetics" 149), thereby transforming the passive process of merely getting old into an active practice of "poetic aging" (Reading Our Lives x). 
Bohumil Hrabal's Too Loud a Solitude, a novella which for a long time has enjoyed cult status in Eastern Europe among both academics and the general public, offers a significant contribution to the issue of aging. In line with Falkner and Carpentieri's argument, yet differing from their ancient and medieval texts, Hrabal's poetics challenges the prevailing conception of aging in the modern West as a linear development. It contests the idea that growing older implies a straight course of development, either one of progress (attainment of experience, maturity, and wisdom), deterioration (physical and mental decline), or a combination of the two (progress of the mind accompanied by deterioration of the body). Narrative gerontologists' notion of aging poetically belongs to this linear image of human life. Although Too Loud a Solitude uses anachrony to return to the protagonist-narrator's past to reveal his earlier conflicts, these returns are not retrospective reconstructions of his life trajectory with the goal of bestowing coherence on it, as in gerontologists' practice of life review. The protagonist-narrator is not storying his experiences so that they display unity and meaning as a whole. Hrabal's poetics is closer to Lively's Moon Tiger in that both narratives condense the character's life into the present moment in which the present and the past coexist, with the past spontaneously intervening in the present through memory without imposing sequential order on the coexistence of the past and the present. However, in Too Loud a Solitude the simultaneity of the past and the present is not a manifestation of a protagonist's at once multiple and continuous identity, as in Moon Tiger. In Hrabal's novella simultaneity pertains less to the wealth of memories that comprise the self than to a specific mode of being that is rooted in the present moment. Hrabal's protagonist-narrator is open to change, but, unlike for gerontologists, this change is neither teleologically driven nor propelled by a quest for totality, coherence, and meaning.

\section{Learning to Accept the World}

Haňt'a, the protagonist-narrator in Too Loud a Solitude, is a recluse who spends most of his time at work where he compacts old paper, drinks beer, and reads discarded books. ${ }^{1}$ In the opening lines of his narrative he describes how he has become who he is:

\footnotetext{
${ }^{1}$ For thirty-five years, Haňt'a has been compressing old paper and castoff books in the cellar of a small wastepaper collection facility in the city center of Prague. To cope with his taxing job-apart from destroying masterpieces of human civilization and other books that the communist regime deems politically inadmissible, he inadvertently kills
} 
For thirty-five years now I've been in wastepaper, and it's my love story. For thirty-five years I've been compacting wastepaper and books, for thirty-five years I've been smearing myself with letters, so that now I resemble encyclopedias of which I've compacted a good three tons over the years, I'm a jug filled with water of life and death, I only have to lean over a little and beautiful thoughts flow out of me, I'm educated so unwittingly that I don't even know which thoughts are mine and from me and which I've read in books, and so, after these thirty-five years I've become connected with myself and the world around me, because when I read I'm not really reading, I dip my beak into a beautiful sentence and suck it like a bonbon, as if drinking a glass of liqueur so long that the thought dissolves in me like alcohol, so long that it infuses me, that it gets not only to my brain and heart, but rattles my veins all the way to the roots of each blood vessel. (Too Loud a Solitude 1-2) ${ }^{2}$

Haňt'a's way of reading is both destructive and creative. Like the physical destruction that he inflicts on the discarded books and that he offsets with his creative attention to each bale, his way of reading destroys original ideas while at the same time endowing them with new life. This creation in destruction is more than a byproduct of the transfer of ideas across distant eras, as Zuzana Stolz-Hladká suggests (44). ${ }^{3}$ Haňt'a is an eclectic reader who is not interested in faithfully

mice that live in the old paper and often end up in the press- he gives each bale unique character by depositing an open book by his favorite writer at its heart and decorating its exteriors with reproductions of famous paintings. The narrative is cyclical and not much happens. From time to time Haňt'a meets with an ex-professor of aesthetics to give him salvaged books, with university-educated people who after the communist revolution were demoted to manual laborers, and with two gypsy women who collect wastepaper for a living. Mostly, however, he presses paper, reads, drinks beer, and muses over the apparitions of writers, philosophers, and historical figures that regularly call on him together with the memories of his past. The plot accelerates after he visits an enormous new press in the Prague-Bubny suburb operated by a group of young and efficient workers. Haňt'a's world of introspective work and recurring situations seems to be coming to an end when the following day he is replaced by two similarly industrious youths. Unable to imagine changing his profession, he lies down in his press to commit suicide, only to wake up drunk in the park.

${ }^{2}$ Hereafter abbreviated TLS. English translations are used whenever possible, and often modified to follow original texts more closely. Where English translations were unavailable, translations are mine and references are given to original editions. In the case of Too Loud a Solitude, I frequently adjust Michael Heim's translation, which tends to embellish the Czech original by correcting its unusual grammar and word order, removing repetitions, amending syntax, and omitting parts of sentences and sometimes entire passages. I point out Heim's divergence from the Czech original whenever pertinent to my argument. Page references to the Czech original (Hrabal Př́liš hlučná samota) are included with the abbreviation PHS for readers who wish to compare the translations.

${ }^{3}$ Stolz-Hladká (44) argues that Haňt'a is a link in the chain of intellectual communication that starts with writer's thoughts, which are transformed into books, which in turn are transformed back to thoughts by Haňt'a, with every step inevitably triggering shifts in meaning. 
restoring original ideas. He selects ideas that personally appeal to him, contemplates them, and returns to them later in light of new enticing ideas. What is more, even the ideas that he selects come to him by chance: "I smell the text and then, in a Homeric-like prophecy, read the first sentence on which I lay my eyes" (TLS 5; PHS 361). Heike Winkel (182) notes that Haňt'a's reading is fortuitous also on account of the books that are available to him, namely books that have been recently thrown away: "books that have turned up in my cellar unexpectedly, much as I myself turned up here" (TLS 6; PHS 362).

Haňt'a's eclectic, fortuitous, and creatively destructive way of reading is complemented by his narrative style. The opening passage continues: "my brain is a mass of hydraulically compressed thoughts, a bale of ideas, Cinderella's nut is my head" (TLS 2; PHS 360). These lines, together with the preceding ones, are creatively destructive on account of borrowing from and rewriting a poem "Poezie" by Jiř́i Kolář: "I am a mouth without lips / And a hand without fingers / Cinderella with an empty nutshell / A being undesired by time I murmur / I am the dead water of life" (20). ${ }^{4}$ Haňt'a is not a dead water of life, but a jug that contains the water of both life and death. By neutralizing Kolář's existential take on the Czech folkloristic tradition, Hrabal returns to the latter's emphasis on magic, with the difference that in Hannt'a the two types of water are mixed together to create something new, unlike in Czech folklore in which they are two separate potions that bring back to life what has been gone (most often a dead person, who must be first sprinkled with dead water to heal the body and subsequently with live water to resuscitate it). Magic applies also to the line "Cinderella's nut is my head." Instead of an empty shell, Haňt'a's head is filled with magical content over which he, like Cinderella who does not know exactly which dress will come out of her next nut, has no control. ${ }^{5}$

For Han̆t'a, books are tools in the creatively destructive process of borrowing ideas and modifying them to his personal use. He and his friends read in anticipation "that one day we will read something that changes us qualitatively" ( $T L S 66 ; P H S 387$ ). They want to evolve, change, and move somewhere else, and books help them to achieve this: "any book worth its salt always points out and elsewhere" (TLS 2;

${ }^{4}$ Hrabal undoubtedly knew this poem. Kolář was a major inspiration for him in his early artistic attempts in the 1940s and the two became close friends in the 1950s. For details about their relationship, see Schreiberová (2014).

${ }^{5}$ The Cinderella story that Czechs are familiar with differs from the one that English speakers know: Cinderella is given three magical nuts, each of which she cracks open before going to a ball, because she has nothing suitable to wear and the nuts are supposed to help her. 
PHS 360). This move out and elsewhere is also the reason for Haňt'a's copious consumption of beer: "I drink to facilitate thinking, to get more easily to the very heart of texts" (TLS 3; PHS 360). Unlike his first love Mančinka, who was terrified of books and who read "only to fall asleep" (TLS 75; PHS 391), Haňt'a reads and drinks to become more sensitive: "I drink so that what I read never lets me sleep, so that it gives me the shivers" (TLS 3; PHS 360). This sensitivity, in turn, connects Haňt'a's more tightly with himself and the world. As he repeats on a number of occassions, his creatively destructive reading and drinking has achieved exactly this: "after these thirty-five years I've become connected with myself and the world around me" (TLS 1; PHS 360); "my life is inextricably connected with these mice" (TLS 15; PHS 365); "my fate is connected through and through" (TLS 18; PHS 366).

Nevertheless, reading also makes Haňt'a strangely detached: "when I start reading, I'm somewhere completely different, I'm in the text" (TLS 7; PHS 362). This detachment persists after he stops reading: "And so detached [zcizeny] and self-involved I also go home from work, walking the streets quietly and in deep meditation [...] subconsciously unconscious and half-asleep, in subliminal inspiration" (TLS 7; PHS 362). Haňt'a's detachment is not a symptom of his loss of autonomy, owing to his reading too much and fetishizing the written word, as Alfred Thomas claims (106). If anything, Haňt'a's imaginative way of reading bolsters his autonomy. The key to understanding the apparent contradiction between Haňt'a's connectivity and his detachment is the uncommon word zcizený which describes his detached state of mind when walking home. This word is used again when Haňt'a narrates how his uncle and his friends enjoy drinking and riding an old train engine that his uncle installed in his garden after he retired from the railways: "all of them were solely preoccupied with their games [byli zcizeni do suých her]" (TLS 19; PHS 367). Haňt'a and his uncle are not absentminded, let alone alienated. They are deeply involved with whatever they are doing.

After thirty-five years of his reading-and-drinking-induced connectivity with himself and the world, Haňt'a has come to the following realization: "It is by books and from them that I've learnt that the heavens are not humane at all and that any person with a head on his shoulders is not humane either, not that he would not want to, but because it goes against common sense" (TLS 3; PHS 360-1). Although he refers to books in plural, this realization is a paraphrasis of the opening lines of chapter five in Lao Tzu's Tao Te Ching: "Heaven and earth are ruthless, and treat the myriad creatures as straw dogs; the 
sage is ruthless, and treats the people as straw dogs" (9). ${ }^{6}$ According to Lao Tzu, the world is ruthless, but in a neutral manner, as it were. All creatures are subject to adverse events, such as floods, draughts, earthquakes, and illnesses, but none of these events are personally directed against them. These events follow natural laws, and the heavens do not remedy or make exceptions to these laws. Consequently, one needs to become ruthless as well, obey the laws of nature, and accept what happens. Haňt'a agrees with this interpretation of the world. As he suggests in his remark about the two gypsy women who have their photograph taken every day with a camera without film, all we have is this world and to hope for a better one is make-believe: "they looked forward to their portraits like Christians to heaven and paradise" ( TLS 37; PHS 375).

Haňt'a arrives at his discovery that one has to accept the world as it is slowly, by reconciling himself with his personal losses and the ensuing grief. The narrative contains references, albeit brief and scattered non-chronologically, to five incidents of loss in Haňt'a's past. Chronologically first is the break-up with Mančinka, who left him because she could not deal with her shame after soiling herself in his company. The second is the loss of the gypsy girl with whom he lived during the war. Significantly, this incident receives more space than the others and resurfaces several times (it is also invoked at the crucial point at the end of the narrative, as we will see later). As Haňt'a recalls, he spent many quiet evenings with the gypsy girl, eating together, drinking beer, and watching shadows from the stove flicker on the ceiling. They did not speak much, so little in fact that they did not even know each other's names, which echoes Haňt'a's relationship with the two gypsy collectors of wastepaper who call him tato (father) and he calls them by the different colors of their skirts. One day she disappeared: "she was transported to a concentration camp from which she never returned, she was burnt somewhere in Majdanek or Auschwitz in cremation furnaces" (TLS 59-60; PHS 384). ${ }^{7}$

\footnotetext{
${ }^{6}$ Charles Muller's translation of Tao Te Ching renders these lines: "Heaven and Earth are not humane / And regard the people as straw dogs. / The sage is not humane / And regards all things as straw dogs" (7). In his own idiosyncratic interpretation of Lao Tzu, Haňt'a makes use of both "ruthless" and "not humane."

${ }^{7}$ Urs Heftrich takes the nonchalant statement "somewhere in Majdanek or Auschwitz" for a declaration of fact, presuming that it was Auschwitz, which is impossible because Haňt'a was still with the gypsy girl in the fall of 1944 (Smutek 40). As Jana Horváthová points out, after August 3, 1944, when all remaining Roma prisoners in Auschwitz were killed, there were no more transports of Czech Roma prisoners to Auschwitz (170). Haňt'a's statement is not a declaration of fact, but a synecdoche for concentration camp. Its casual delivery divulges the extent of his trauma: he has never been able to investigate where the gypsy girl was sent.
} 
Haňt'a was still humane when the gypsy girl was killed: "The heavens are not humane, but back then I still was" (TLS 60; PHS 384-5). This changes with the third incident, the devastation of the Prussian library and the selling off what was left of it: "Back then I already mustered the strength to look upon misfortune with composure, to still my emotions" (TLS 12; PHS 364). Likening this strength to that of Leonardo da Vinci, who was able to observe, "attentively and with contentment" soldiers who were blowing to pieces his statue (TLS 12; PHS 364), Haňt'a became ruthless in accepting what happens. When later his mother dies, he is stronger and calmer than before, though he still feels some anguish: "I just stood and stared, in exactly the same way as when the train that was taking the beautiful libraries off to Switzerland and Austria was disappearing in the distance" (TLS 13; PHS 364). This anguish is gone with the fifth incident. When his uncle dies, Haňt'a is unperturbed and quietly collects the remains of his uncle's decomposing body from the floor.

\section{Compassion and Overcoming the Need for Recognition}

After thirty-five years Haňt'a has learned to accept the ruthless world. However, he has been less successful with the second line in Lao Tzu's quote. He still suffers on account of his participation in this world: "rare books perish in my hydraulic press and I am unable to stop their stream and flow" (TLS 3; PHS 361), "everyday I compact a hundred innocent mice" (TLS 17; PHS 366). He tries to rationalize what he does by citing Hegel's dictum that destruction is positive because it refreshes the world and helps it move forward. When he hears a story about a war that took place in the Prague sewers between two species of rats, and that as soon as one side won it immediately split into two clans which are now battling again, he interprets it in unmistakably Hegelian terms: "the winning side will again split up into two opposing camps, like gases and metals and all organic matter in the world, so that life can revitalize itself through battle, and then, minute by minute an equilibrium arises thanks to the desire to balance the opposites, and thus the world in its entirety never limps, not even for a second" (TLS 23; PHS 368). He views his job as part of this revitalizing battle: "what I was doing, that job, someone's got to do it" (TLS 52; PHS 381). Hence he must be ruthless in executing it: "a fierce battle is taking place in all the sewers, so not even rat heavens are humane, and so I can't be humane either" (TLS 25; PHS 369). 
And yet, Haňt'a is not completely convinced by his Hegelian rationalization. The conclusion of his story about the war of rats betrays his doubt as to whether conflict and destruction are truly inevitable: "And while in the gutters and sewers of the capital city of Prague two clans of rats are ousting each other in an ostensibly senseless war, the cellars are headquarters for Prague's fallen angels, university-educated men who have lost a battle they never fought" (TLS 24; PHS 369). Even without the rhetorical question, "What for, and why?," which closes the chapter in the second version of the novella but which is deleted in the final version, it is evident that Haňt'a has misgivings about Hegel's combatant attitude to the world: "the seemingly final war of rats that will end with great cheers, which will last until there is a reason to start the whole thing again" (TLS 25; PHS 369). ${ }^{8}$

Even though Haňt'a accepts the ruthless world, he remains skeptical about conflict and destruction as the basis of his actions. But he is equally hesitant about an opposing attitude-Christian love. He cannot forget Jesus's proclamation, "I came not to bring peace, but a sword" (TLS 23; PHS 368), and later he has visions of Jesus "always full of fervor amidst a group of young men and pretty ladies" (TLS 34; PHS 373) and as he "is raising an imperious arm and with a mighty gesture damns his enemies" (TLS 40; PHS 376). Schopenhauer's compassion emerges as an alternative. One day after finishing his shift Haňt'a notices that a mouse is staring at him: "With a flash of lightening Arthur Schopenhauer revealed to me that the highest law is love and that love is compassion" (TLS 53; PHS 382). Unlike with Hegel's conflict and Christian love, Haňt'a embraces compassion, with the proviso that one must not proselytize it too vigorously: "I was glad, however, that neither Hegel nor Schopenhauer were leaders of opposing armies, because the two would wage the same war as those two rat clans in the sewers and gutters of the Prague underground" ( TLS 54; PHS 382).

The reflections on Hegel, Jesus, and Schopenhauer bring to the fore Haňt'a's distrust in the position of strength and fervor. The pinnacle of this position is the triumphant Hitler and the crowds of "cheering men and women and children" (TLS 60; PHS 385), and also the enthusiastic socialist workers at the new press in Prague-Bubny. These triumphant crowds are in stark contrast with the demure gypsy girl. The motif of cleanliness and efficiency further accentuates this contrast. The gypsy girl's indifference to her hygiene and attire stands out against the cleanliness and sartorial concerns of the impassioned 
crowds. Hitler and his hailing masses are clean and well-dressed, as are the young Bubny workers, who, unlike Haňt'a who "always worked with bare hands so that I could taste the paper in my fingers" (TLS 64; PHS 386), wear immaculate uniforms and protective gloves. For Haňt'a, cleanliness, efficiency, and effectiveness are inhuman. The Bubny workers compress discarded books "mercilessly and inhumanly" on a giant mechanized press "without even a single page sullying the human eye and human brain and heart" (TLS 73, 65; PHS 390, 386). This clean, efficient, and inhuman handling of books uncannily resonates with the death administered in Hitler's concentration camps and at the fully automatized communist poultry farm where workers are "working cheerfully and with humor" (TLS 69; PHS 389).

The problem with the position of strength and fervor as manifested in the collective celebrations of the victorious rats, the cheers of Hitler's crowds, the verve of the socialist workers, and to some extent even the vigor and devotion of Jesus and his young followers, is that it perpetuates self-righteousness and intolerance. Someone always suffers as a consequence of the crowds' certitude of their ideals and determination to implement them. The gypsy girl is an antithesis of this position: "she had never cheered, she didn't want anything except to feed the fire in the stove and cook her potato goulash with horse salami and fetch beer from the pub in my massive jug" (TLS 60; PHS 385). Haňt'a still believes that he does what he has to. His job is to press old paper, which inexorably brings death to the mice that live in it. But he executes his job without determination and sense of triumph. He is cognizant of what his actions entail. He is ruthless, but also kind: his ruthlessness is replete with gentleness, weakness, and compassion. ${ }^{9}$

Haňt'a's contradictory state of compassionate ruthlessness is a product of aging. This becomes clear in his comparison of Lao Tzu and Jesus. One day, apparitions of these two historical figures visit him in his cellar: "for the first time I realized how terribly important their age is for an understanding of their way of thinking" (TLS 33; PHS 373). Whereas Jesus is a "playboy," "a tennis champion who has just won Wimbledon" (TLS 40; PHS 376), "a fervent young man intent on changing the world" (TLS 33; PHS 373), Lao Tzu is "an old man with a wrinkled face" who accepts the world (TLS 33; PHS 373). While Jesus

\footnotetext{
${ }^{9}$ In his autobiographical texts Hrabal often talks about his agony of keeping the swelling clowder of his cats in check by euthanizing some of the newborn, something that he must do ruthlessly but also with tenderness and compassion (Pirouettes 77-78; Život 84-88).
} 
is full of "confrontational and dramatic situations," Lao Tzu quietly ruminates about "the insolubility of the moral situation of opposites" (TLS 34; PHS 373). Haňt'a is not quite of Lao Tzu's age-he has five years until retirement, which means that he is fifty-five, and even though the narrative does not indicate Jesus's and Lao Tzu's age, the first version of the novella puts it at thirty for the former and over seventy for the latter-but despite being somewhere on the middle, he feels closer to Lao Tzu than Jesus. This closeness is communicated indirectly, via the comparison between Haňt'a's aging face and the time-ravaged, "mushroom-like face" of Rembrandt (TLS 14; PHS 365): "I'm already beginning to have the same face of a moldered puff pastry dough, that peeling, urine-soaked wall of a face, I'm already beginning to smile the same half-moronic smile and am beginning to look at the world from the other side of human events and matters" (TLS 15; PHS 365). This smile is no longer that of composure in the face of adversity as when his mother died. It is no longer a smile of a da Vinci-like self-control, but one of a compassionate acceptance of the rutheless world.

And yet, Haňt'a understands and empathizes with Jesus as well, for he too used to be young and wanted to be a playboy (TLS 26; PHS 370). Like Jesus, he liked to be at the center of attention, first as a soccer player (TLS 63; PHS 386), a bit later at the village dance hall with Mančinka-"I kept her twirling so everyone could see what a good dancer I was, how good we looked with Mančinka, what a couple we made" (TLS 27; PHS 370)-and finally at the ski resort with her during their second attempt at a relationship: "all the men envied me my Mančinka" (TLS 29; PHS 371). But in his fifties he is no longer dependent on how others see him. This is in contrast with Mančinka, who has never changed. As the scatological scenes at the dancing hall and the ski resort demonstrate, unlike Haňt'a who on the second occasion was already unruffled by their fall from grace, she was still unable to bear the shaming gaze of the onlookers. These scenes are vital-Michel De Dobbeleer and Dieter De Bruyn object to their exclusion in the recent adaptation of Too Loud a Solitude to a graphic novel-for they mark Haňt'a's evolution from a youngster who craved recognition to a middle-aged man who attaches no importance to it (181).

\section{Hrabal's Poetics}

Haňt'a evolution as a person is defined by his gradual learning to overcome his craving for recognition, accept the ruthless reality, and 
become compassionately ruthless in his attitude to himself and the world. However, in his narrative this evolution is not immediately apparent. He does not narrate a story of his development from a younger age to an older age. He uses anachrony in a very creative fashion: he focuses mostly on events taking place in the present moment, narrates them in the present tense, and includes recourses to the past only when they offer something relevant with respect to what is happening now. Fragments of his past are dispersed throughout his narrative, but it is up to the reader to reconstruct their sequence, such as in the case of the above-discussed incidents of loss and grief. Haňt'a provides only one date-the flying of the kite with the gypsy girl in the fall of 1944. If we follow the clues that Haňt'a leaves in his narrative, we can decipher when other events take place. For instance, when his mother dies, he has been working at the press for ten years; she dies soon after the destruction of the Prussian library, which takes place shortly after the war; this means that her death occurs in or around 1947, which in turn puts the start of Haňt'a's job at the press in 1937; and given that he has been working there for thirty-five years, he narrates his story in $1972 .{ }^{10}$

The creative use of anachrony is the centerpiece of Hrabal's poetics in Too Loud a Solitude. The fact that Haňt'a's narrative pivots around his experiences in the present moment, with occasional non-chronological snippets of the past, requires the reader to actively seek and restore the expositional past to be able to appreciate the full scope of Haňt'a's development. This is in contrast with Hrabal's previous novel, I Served the King of England. Indeed, Too Loud a Solitude and I Served the King of England share many similarities, such as the main theme of overcoming one's dependence on the recognition by others. Another similarity are the central motifs of a happy Sisyphus and death as recycling. Haňt'a delights in the unremitting flow of old paper that floods his cellar even though he cannot keep up with it. Likewise, the protagonistnarrator in I Served the King of England, Jan Dítě, loves his job as a mender of forest roads despite the fact that the harsh climate soon reinstates them to their former state of disrepair. The motif of death as recycling appears on a number of occasions in Too Loud a Solitude,

\footnotetext{
${ }^{10}$ Urs Heftrich's argument that Haňt'a started working at the press in 1941 is untenable ("Trauer" 230). Heftrich arrives at this year by taking the date July 1976 printed at the end of the novella and subtracting thirty-five years from it. He not only mistakes the authorial declaration of the date when the manuscript was finished for Han̆t'a's declaration, but also disregards the time clues in Haňt'a's narrative. As biographers have documented, Hrabal started writing Too Loud a Solitude in 1972, a year that coincides with the narrative present from which Haňt'a tells the story (Kotyk et al. 146).
} 
for example when Haňt'a eats the kohlrabi that was fertilized with the ashes of his mother (TLS 14; PHS 364-5), and when he muses over Sandburg's verses that human ashes contain enough phosphorus for a box of matches (TLS 13; PHS 364). In I Served the King of England this motif appears several times as well, most prominently when Dítě drinks from a brook that passes through a cemetery and reflects on how the nutrients from decomposing bodies enrich the water, dreaming of being buried at this cemetery at the top of a hill, for then rain will carry his remains into the rivers that flow to both the Black Sea and the North Sea, where he will fertilize new life (230-232). ${ }^{11}$

In spite of these thematic similarities, however, the two texts differ significantly in their narrative technique. I Served the King of England is narrated chronologically, with the protagonist-narrator taking us on a more or less linear journey of his life. For most of this journey the narrator, faithful to his name, Dítě (Child), recounts his lifestory with little critical reflection. Although much of what he tells us about his past is deplorable-for example, his collaboration with the Nazis and enriching himself by selling valuables taken from the deported Jews-he narrates these events without any attempt at analysis. In fact, he seems almost proud of himself, as the repeated phrase, "Now listen up to what I'm going to tell you [Dávejte pozor, co vám ted'ka řeknu]," suggests. ${ }^{12}$ It is only at the end of his narrative that he makes his position clear. His craving of success and recognition made him act in a questionable way. What is more, he was never happy because he was always doing things to impress others. Even more importantly, when at the end of his narrative he reveals where aging has brought him, he does so in a series of discursive statements: "But to be reflected in human eyes and praised, all that had left me" (226), "a true and cosmopolitan human being is someone who is capable of withdrawing into anonymity" (235), "now that I had been struck from the heavens down below again, to my knees, I realized that my star was brighter than ever, that only now I would be able to look into its very heart, at its center, that my eyes had to be weakened by everything I had

\footnotetext{
${ }^{11}$ The motif of death as recycling can be found already in Hrabal's early works-in the short story "Mr. Kafka," for instance: "have yourself cremated and bequeath your ashes unto me and I'll scour my forks and knifes with you so that something splendid is happening with you" ( $M r$. Kafka 18).

${ }^{12}$ This phrase, which opens each chapter, is left out in the English translation together with "Is that enough for you? I'm done for today," which ends each chapter, and "Is that enough for you? But now I'm really done," which ends the novel.
} 
lived through so that they could experience more and endure more. Perhaps I had to become weak to see and learn more" (207).

One can imagine that Haňt'a would endorse these revelations. He, too, has become weak, anonymous, and with no desire to be praised. However, because he uses anachrony more creatively than Dítě, his revelations are irreducible to discursive statements. He does not take us on a chronological journey of his life that ends with a move to the country where one finally finds oneself. Dítě explains his move to the country as an "escape into solitude" (235), which he tautologically describes as "the kind of serenity that can secure one against the desire to escape from solitude" (228). In contrast, Haňt'a is a solitary person already at the beginning of his narrative: "I'm never lonely, I'm only alone so that I can live in a solitude populated with thoughts" (TLS 9; PHS 363). He is also inquisitive and self-reflective from the outset. His narrative, as well as the narrated action, is marked by no radical shifts. Unlike Dítě, who reveals only at the end what he has known all along, namely that how he lived before his relocation to the country was a mistake, Haňt'a does not hide his thoughts. On the contrary, he constantly reflects on what is happening and makes his dialogue with himself accessible to the reader all along.

Apart from Hrabal's creative use of anachrony, the poetics in Too Loud a Solitude consists of a very idiosyncratic language and style. The most salient feature of this language is its formal nature. Haňt'a lives in a reality that is far from refined, yet he narrates his story in a formal language. This discrepancy does not mean, as Miroslav Červenka claims, that Haňt'a introduces distance into his narrative. Červenka argues that the clash between the dreariness of Haňt'a's day-to-day life as a character and the ceremoniousness with which he treats it as a narrator gives his monologue a distant feel (209). I disagree. Formal language does not usher an additional voice to Haňt'a's monologue that does not fully belong to him because it is extraneous to his reality. Haňt'a genuinely sees beauty in his humdrum existence. Arguably, it is informal language that would introduce another, foreign voice to his narrative, for then he would live in crude reality and speak in a correspondingly crude language all the while extolling this reality.

As to Hrabal's style, it has three prominent traits. The most striking is the abundance of tropes, especially oxymorons, metaphors, and similes. As Radko Pytlík has pointed out (92), oxymorons, such as "gentle butcher" (TLS 3; PHS 361) and "beautiful misery" (TLS 18; PHS 366), are more than ornaments: they are a counterpart at the level of style to Haňt'a's method of comparing and bringing together 
opposing philosophical concepts. Metaphors and similes are indicative of how Haňt'a perceives the world. They show him as a compassionate person who is nonetheless attached to his bleak reality: "the Gypsy women were touching each other with their shoulders like a pair of horses that are destined to pull their carriage together until the day they are taken to the slaughterhouse" (TLS 37; PHS 374); "the flies in the cellar were embroidering an immense tableau vivant in the air made up of constantly shifting curves and splashes, exactly how Jackson Pollock assembled his gigantic paintings by pouring paint on them" (TLS 33; PHS 373); "the wastepaper was rotting like old roots in a swamp and was exuding a sweet smell of a home-made cheese that was left forgotten in the pot for half a year" (TLS 51; PHS 380). Milan Jankovič argues that tropes, together with the excessive accumulation of synonyms in Haňt'a's speech, accelerate the initial image and let it grow and ramify, which makes this speech transcend empirical reality ("Epilogue" 127). This is an accurate observation, but one should add that Haňt'a's speech at the same time remains firmly rooted in reality. Hrabal's extravagant style of abundant tropes and synonyms has a dual effect of adhering to Haňt'a's existence in the quotidian while simultaneously transcending it by injecting it with beauty, curiosity, and excitement.

The second trait of Hrabal's style is the sense of flow it creates. This is achieved primarily by dispensing with paragraphs and by utilizing long sentences in which clauses are added freely and separated with commas instead of the grammatically correct periods, as in the opening passage of the novella cited above. Less frequently, periods are replaced with three dots, but the effect is the same, as is the effect of omitting italics in titles of books and inverted commas in direct speech and citations. ${ }^{13}$ Haňt'a's monologue flows without concern for the established norms of the written text. And yet, his narrative is not unstructured. It is interlaced with powerful instances of repetition. Milan Jankovič distinguishes among three types of repetition at the level of the sentence: similarity of sentence parts in terms of their intonation, anaphoric reiteration of words at the beginning of successive clauses, and euphony and alliteration produced by the metrical distribution of the utterance ("Čas" 235-253). Repetition can be detected at the level of composition as well. The most noticeable is the opening phrase that in slight variations punctuates the narrative:

\footnotetext{
${ }^{13}$ The English translation disregards these stylistic choices. Heim organizes the text into paragraphs, divides long sentences into shorter units, substitutes periods for commas and three dots, and introduces inverted commas and italics.
} 
"for thirty-five years I've been packing wastepaper [tricet pět let balím starý papir]" (TLS 2, 25; PHS 360, 369); "for thirty-five years I've been compressing wastepaper" (TLS 1; PHS 360); "for thirty-five years I've been compressing wastepaper on a hydraulic press" (TLS 8; PHS 362 ), and so on. These variations play an important role in building suspense. For most of the narrative they appear in the present tense, only to suddenly switch to the past: "for thirty-five years I was packing wastepaper [třicet pět let jsem balil starý papir]" (TLS 62; PHS 385). The repeated use of the phrase in the present tense throws into sharp relief the sudden switch to the past. It increases anticipation by signaling that something momentous has happened. At the level of composition, the narrator also uses repetition by returning to already narrated events and motifs, especially before introducing key new events and motifs. This use of repetition highlights what matters in the narrative and amplifies connections that otherwise might go unnoticed.

And the third prominent trait of Hrabal's style is his choice of narrative tense. The fact that Haňt'a narrates mostly in the present tense brings to the fore his incompletion, as both the protagonist and the narrator. As he narrates, he continues experiencing new things, which means that not everything in his narrative when it ends was known to him when he embarked on it. Although he might have an idea about what he wants to communicate in his narrative when he starts it, this idea is open to change as he goes on with his story. As he continues to live and undergoes new experiences, he incorporates them into his story. These experiences could not have been anticipated at the onset of the story. The narrative simultaneously conveys what Haňt'a has learnt from aging-namely overcoming the struggle for recognition, accepting the pitiless world, and becoming compassionately ruthless-while at the same time testing whether he has internalized these discoveries. The interval that passes between the beginning and the end of the narrative is a test whether Haňt'a has truly accepted the ruthless world. Can he face fresh challenges that this world presents after he began narrating? Specifically, can he accept the dismissal from his job and thus the end of his three decades-long lifestyle?

\section{Aging as an Ongoing Task}

In I Served the King of England the linear narrative of the protagonistnarrator's life leads to a series of revelations at the end. He narrates his story in the past tense and at the end tells us what he has learnt: that his struggle for recognition was vain and that now he finally can live 
the last phase of his life free of it. Haňt'a, too, realizes that he does not need to be recognized by others. However, in his case this realization takes place in the expositional past and results in a series of further realizations pertaining to ruthlessness and compassion. In Too Loud a Solitude older age is not a phase of life but a continuing process that puts one's realizations and transformations, such as overcoming the struggle for recognition, through tests and trials. For Haňt'a, no realization is ever final. The end of his narrative is crucial in this respect. In the first two versions, the novella ends with Haňt'a's suicide. After refreshing himself in several pubs following his dismissal, Haňt'a goes to his workplace, climbs into the press, and sets it in motion. Before he is crushed to death, an image of flying the kite with the gypsy girl springs to his mind and he suddenly remembers her name. The first version ends: "I cried out: < Now I've remembered, Ilonka was her name! > Ilonka! And the press was happily clinking on and I no longer knew about it" (Hlučná samota 170). The second: "Yes, her name was Ilonka... now I've remembered" (241). But in the final version the suicide is relegated to a dream:

I cried out... Ilonka! And I opened my eyes, I was looking at my lap, with my both hands I was holding an armful of garden pansies pulled out with their roots, my lap full of soil, I was looking dumbly at the sand, and when I looked up, the turquoise green and velvet violet skirts were standing in front of me in the light of the sodium-vapor lamp, when I bent my head further back I saw those two dear Gypsies of mine, all fired-up, behind them the neon dial and hands on the New Town Tower shone through the trees, the turquoise green was shaking me and shouting... Father, for the wounds of God, the heart of Jesus, what on earth are you doing here? I was sitting on a bench, smiling innocently, not remembering anything, I saw nothing, heard nothing, because I might have been already in the heart of the garden of paradise. And so I could not have seen or heard how my dear Gypsies, hanging onto two Gypsy men, strode their way across Charles Square from left to right in a polka step and disappeared in the bend of a sand path, somewhere behind the thick bushes. $(P H S 401)^{14}$

This passage has been controversial. Susanna Roth believes that ending the story with suicide is more in line with the theme of the changing times which render Haňt'a obsolete, and that Hrabal altered the end to satisfy communist censors (131). Indeed, some elements in the narrative seem to support her hypothesis that the added pas-

\footnotetext{
${ }^{14}$ Heim's translation does not include this passage. It ends the story with Haňt'a's suicide, though the final lines of his translation do not abide by any of the available three versions of the Czech original: "ILONKA. Yes, that was her name" (TLS 98).
} 
sage is at odds with what happened earlier. For example, the shift in the tense of the recurrent opening phrase from the present to the past can be taken for a sign of Haňt'a's nearing end. So can be the motif of reciprocal justice that haunts Haňt'a: "every transgression turns against us" (TLS 17; PHS 366). This motif is introduced in two stories: a forester who killed a marten for decimating his chicken stock by hammering a nail into its head, and whose son died a year later when a live wire struck his head; and a hunter who killed hedgehogs by driving sticks through their stomachs and who later died of stomach cancer (TLS 17-18; PHS 366). ${ }^{15}$ Like the forester and the hunter, Haňt'a has killed animals and therefore deserves a matching death. He has pressed mice and so should perish in the press. Another example that seems to intimate Hańt'a's looming end is the story of the monks who, after Copernicus discovered that the Earth is not the center of the universe, committed suicide, unable to imagine living in such a radically different world (TLS 79; PHS 392). And the last example is the staccato current into which the narrative dissolves just before the suicide:

... I'm in the Black Brewery again, I ordered a glass of rum and then a beer and again the rum, not until we're crushed do we show what we're made of, the neon clock on the New Town Tower is already shining through the branches against the dark sky, as a boy I used to dream of becoming a millionaire and buying phosphorescent hands and dials for clocks in all cities, the mangled books are making a final attempt to burst out of the bale, the portrait of a man with a mushroom-like face ... (TLS 94; PHS 399)

Nevertheless, the added passage changes the meaning of these apparent intimations of Haňt'a's death. It becomes clear that after leaving the last pub, Haňt'a made it only as far as the park where he sat down on a bench and fell asleep. The walk to his workplace is already a dream, from which he wakes up on the same bench facing the same neon dial and hands. The staccato current is not an ominous warning of an impending end, but a literary expression of Haňt'a's drunken state of mind. Similarly, the motifs of reciprocal justice and suicidal monks are not hints at Haňt'a's imminent death, but manifestations of his negative thoughts prompted by his dismissal. Haňt'a lives on, not because, as Lubomír Doležel argues, Hrabal became frightened by the radical nature of his narrative experiment in the first and the second versions of the novella, in which the narrator

\footnotetext{
${ }^{15}$ Heim makes the forester and the hunter into one person and fails to specify how the forester's son died, thereby diluting the theme of reciprocal justice.
} 
dies and thereby turns his story into one narrated by a dead person (245). Hrabal did not recoil from this experiment before. In the novella Closely Watched Trains the protagonist-narrator narrates his own death. Nor did Hrabal want to placate the censors, as Roth argues. Too Loud a Solitude contains more politically contentious issues than suicide, such as Haňt'a's sympathy with the declassed intelligentsia and his disparagement of socialist workers. What is more, even with the added passage the novella did not pass the censors and yet Hrabal kept it in the manuscript. When the story finally appeared, admittedly in a segmented form of separate sections of the novella alternating with sections of another text, the passage in question was included (Kluby 128-129). In the postface to the volume, Hrabal suggests why this passage is an integral component of Haňt'a's story. Haňt'a is one of those characters who, notwithstanding difficulties and failures, continue living and exploring what life has to offer: "Their poetry thus breaks out of its shell and hatches again and again every day, only to come across another ceiling, a shell of another egg beyond which they sense other spheres that seduce them" (Kluby 131). That Haňt'a lives on validates his attitude of the acceptance of the world. It demonstrates that he is capable of turning challenges into stimuli for adaptation and that he regards new shells, not as limitations, but as an invitation to find out what lies beyond them.

The added passage changes the meaning of the potentially misleading statement that occurs before the dream of suicide: "I've started entering a world in which I have never been before" (TLS 97; PHS 400). This statement refers to Haňt'a's new world without his old job, not to the afterlife. When he wakes up in the park and calls it the heart of the garden of paradise, he paraphrases the line from Novalis he mentioned earlier: "Every beloved object is the center point of the garden of paradise" (TLS 97; PHS 400). ${ }^{16} \mathrm{He}$ affirms that anything can be a source of happiness. Although his new life means the end of the old joys of reading discarded books and saving them for his friends-"gone were the days of small joys" (TLS 66; PHS 387)—it is not the end of all joys. When after his dismissal Haňt'a meets the ex-professor of aesthetics and informs him that he will no longer be able to get books for him, the ex-professor still gives him the usual tip to make his search easier. To Haňt'a's question, "to search, but for what?" he answers: "some other joys" (TLS 84; PHS 395). Haňt'a's

\footnotetext{
${ }^{16}$ The standard English translation of Novalis's apothegm, "Jeder geliebte Gegenstand ist der Mittelpunkt eines Paradieses," is "Every beloved object is the center of a paradise" (31).
} 
dismissal forces him to adapt, yet again. It tests his ability to move on, elsewhere, and beyond.

\section{Disillusionment and Adaption}

Critics have interpreted Haňt'a as a quixotic character who is out of sync with reality. Dragoslav Slejška considers him a modern-day Don Quixote who strives to preserve an old-fashioned, individual attitude to work, reading, and the world at a time when it is no longer feasible (101). According to Jiří Pelán, Haňt'a's effort to find humane order in an inhumane world is similarly quixotic: his attempt to realize a utopian idea of justice, truth, and beauty in a world in which not even the heavens are humane is doomed to failure ("Quijotismus" 467, 470). Too Loud a Solitude does not warrant this interpretation. Haňt'a does not try to preserve the old world or realize an ideal one. Instead, he continually adapts to the existing one. Unlike Don Quixote, Haňt'a reflects on reality and adapts to it. Also in contrast with Don Quixote, whose actions and perception of the world have been formed exclusively by reading chivalric romances, Haňt'a reads a wide array of books, which moreover he critically evaluates vis-à-vis one another and his own experiences. Rather than quixotic, he is rational and capable of adjusting to reality, finding his niche in it, and reinventing himself as his circumstances change. Not even his ethical concerns, such as destroying precious books and killing mice, are symptoms of his outdatedness and intractable nature. Nor do these concerns interfere with the amoralism and non-judgmental attitude that characterized Hrabal's works prior to Too Loud a Solitude, as Pelán argues ("Bohumil" 17). Haňt'a is not a moralist. He accepts the world, including what he does not like about it.

Despite his hardships, Haňt'a is not disillusioned. This is in stark contrast with Don Quixote, who at the end of Cervantes's novel is disenchanted and crestfallen. Instead of learning from his mistakes, he apologizes for the havoc he has caused, writes a will which disinherits his niece if she marries someone who reads chivalric romances, and dies. Don Quixote is a precursor of what is to define the modern era. He encapsulates a deeply ingrained cliché in modern Western culture that aging implies disillusionment. Adam Phillips wonders how it has come about that we have been educated to have expectations about life that are so likely to leave us feeling defeated: "We must have been wanting the wrong things from life-we must have inherited the wrong cultural ideals-if our experience is one of cumulative disappoint- 
ment" (166). Starting with Don Quixote, modern literary fictions have been instrumental in cultivating these expectations. Most notably, the Bildungsroman has represented aging as maturing and integration to a wider community. These representations extend from triumph, such as in Goethe's Wilhelm Meister, to various degrees of failure and ongoing struggle with social convention, such as Lucien de Rubempré in Balzac's Lost Illusions, who returns to his hometown defeated after his unsuccessful attempt to establish himself in Paris, or Mrs. Transome in George Eliot's Felix Holt, who completes socialization successfully, but continues to strive against social expectations of what a woman in her fifties should be, namely a mother and a wife. More recent fictions rarely subscribe to the Bildungsroman conception of maturity, but even they, as most narratives discussed in the opening section of this essay demonstrate, still bear traces of the belief that aging involves disillusionment, even if one no longer attributable to miscarried socialization but rather to what these narratives postulate as inherent to older age, namely monotony, diminished zest for life, and regret of missed opportunities. Simone de Beauvoir's praise for Michel de Montaigne's Essays is emblematic of the correlation in Western modernity between aging and disillusionment: "The Essais become richer and richer, more and more intimate, original and profound as the author of the book advances in age. He would never have been capable of writing these fine, biting, disillusioned pages upon old age when he was thirty" (159-160). Beauvoir equates richness and depth with disillusionment that only age can bring. This equation is problematic because it promotes particular cultural ideals without examining their legitimacy and assessing their usefulness and applicability.

Naturally, not everyone experiences aging as cumulative disappointment. However, experiencing it as fulfilment is a manifestation of the same cultural ideals and expectations from life. Disappointment and fulfilment, disillusionment and gratification, defeat and successthese are two different outcomes of the same model of human life based on achievement and progress toward goals. Hrabal questions this model. His poetics challenges the prevailing conception of aging in modern literary tradition and society as a linear process, whether one of intellectual growth, expansion of experience, and maturing of emotions, or one of deterioration, physical decline, and weakening of mental capacities. But Hrabal goes beyond questioning and challenging. He formulates an alternative to this conception. Unlike Falkner and Carpentieri's ancient and medieval examples of poetics of aging, Hrabal does not reproduce selected aspects of the dominant 
conception and representation of aging while modifying others. He offers a new notion of aging.

The representation of aging in Too Loud a Solitude defies our persistent need to endow life with meaning. This need is a product of the linear model of life as achievement and progress toward goals. Haňt'a does not strive to give meaning to his life, neither as a character nor as a narrator. He does not engage in what gerontologists allege is a universal procedure of reviewing one's past and systematically reintegrating it into a story of one's life so that it displays coherence and meaning as a whole. This procedure is not a naturally occurring practice, but a reflection of culturally valorized and internalized values and ideas about human existence. Gerontologists' argument that repeated storying and restorying of our life effectively fights disillusionment that often afflicts older age is an extension of the linear model of life which has led to disillusionment in the first place. For Haňt'a, human life and its trajectory are utterly contingent and unpredictable. He has no preconceived ideas about what human life is or should be. Nor does he grant his actions coherence and meaning in his narrative. With no concrete goals to attain and no overall meaning to confer on his life, his aging is a result of the circumstances in which he finds himself at each moment and how he adapts to them. This might strike some as a life lived in vain, without any purpose and meaning. But then again, purpose and meaning are attributes of a specific model of life, not what human life intrinsically has, or even ought to have. Hrabal suggests that one's life does not need a purpose, meaning, and coherence to be rewarding. In fact, it is precisely when we expect it to have these qualities that we are likely to end up disillusioned. ${ }^{17}$

Too Loud a Solitude is not a quixotic tale about a failure to come to terms with reality. It is a story of someone who staunchly adheres to reality. Haňt'a lives, reflects on his life, and tells us about it without knowing where his life or his story will go. What is more, he is fine with this uncertainty and with his conviction that human life does not have a meaning. He does not try to impose rational justification and artificial unity on his life, neither as a character nor as a narrator. He remains rooted in the present moment and reconciled with the reality devoid of meaning-ruthless yet mesmerizing, painful yet

\footnotetext{
${ }^{17}$ These ideas continue to play a central role in Hrabal's work after Too Loud a Solitude, especially in his autobiographical and essayistic writings in the 1980s and 1990s, in which he repeatedly returns to the theme of contingent life without meaning and the role of literature in facilitating one's openness to it. For an analysis of this theme in Hrabal's later work, see my "Literatura a život: sebestylizace jako strategie v autobiografických a esejistických textech Bohumila Hrabala," Ceská literatura (forthcoming 2019).
} 
beautiful. His aging is a process of constant adaptation to his changing surroundings and self-reinvention while doing so. This adaptation and self-reinvention are non-teleological and non-normative. Although his aging generates a degree of continuity-he learns to accept certain things and overcome others - this continuity is not part of a deliberate plan or corroboration of some metaphysical truth about the general course of human life. Haňt'a lives and ages moment by moment, in an always improvised adaptation to reality that has no goal, no predetermined trajectory, and no coherence as a whole.

Bilkent University

\section{WORKS CITED}

Beauvoir, Simone de. The Coming of Age. Translated by Patrick O'Brian, Norton, 1996.

Bernhard, Thomas. Gathering Evidence. A Memoir. Translated by David McLintock, Vintage, 2010.

Butler, R. N. "The Life Review: An Interpretation of Reminiscence in the Aged." Psychiatry, vol. 26, no. 1, 1963, pp. 65-76.

Carpentieri, Nicola. "Towards a Poetics of Ageing. Private and Collective Loss in Ibn Hamdīs' Late Verse." Journal of Transcultural Medieval Studies, vol. 3, no. 1-2, 2016, pp. 119-143.

Céline, Louis-Ferdinand. Rigadoon. Translated by Ralph Manheim, Dalkey Archive, 1997.

—. Castle to Castle. Translated by Ralph Manheim, Dalkey Archive, 1997.

—. North. Translated by Ralph Manheim, Dalkey Archive, 1996.

Červenka, Miroslav. Záznamník. Atlantis, 2008.

Dobbeleer, Michel De, and Dieter De Bruyn. "Graphic Grotesque? Comics Adaptations of Bohumil Hrabal and Bruno Schulz." Slavic and East European Journal, vol. 57, no. 2, 2013, pp. 175-202.

Doležel, Lubomír. "Hra s ich-formou v díle Bohumila Hrabala." Česká literatura, vol. 62, no. 2, 2014, pp. 238-250.

Falkner, Thomas. The Poetics of Old Age in Greek Epic, Lyric, and Tragedy. U of Oklahoma $\mathrm{P}, 1995$.

Gospodinov, Georgi. The Physics of Sorrow. Translated by Angela Rodel, Open Letter, 2015.

Heftrich, Urs. Smutek na vedlejši koleji. Nacistická genocida Romú v českéliterature. Translated by Petr Šourek, Revolver Revue, 2009.

—_. "Trauer auf Umwegen. Der nationalsozialistische Genozid an den Roma im Kontext der tschechischen Literatur." Der nationalsozialistische Genozid an den Roma Osteuropas: Geschichte und künstlerische Verarbeitung, edited by Felicitas Fischer von Weikersthal et al., Böhlau, 2008, pp. 217-244.

Horváthová, Jana. "Smutek na vedlejši koleji. Nacistická genocida Romú v české literatuře by Urs Heftrich.” Bulletin Muzea romské kultury, no. 19, 2010, pp. 169-171.

Hrabal, Bohumil. Př́liš hlučná samota. Spisy, vol. 3, edited by Václav Kadlec and Jiří Pelán, Mladá fronta, 2015.

. Mr. Kafka and Other Tales from the Time of the Cult. Translated by Paul Wilson, New Directions, 2015. 
—. Pirouettes on a Postage Stamp. Translated by David Short, Karolinum, 2008.

—. I Served the King of England. Translated by Paul Wilson, New Directions, 2007.

_. Hlučná samota. Sebrané spisy Bohumila Hrabala, vol. 9, edited by Václav Kadlec, Pražská imaginace, 1994.

—. Too Loud a Solitude. Translated by Michael Henry Heim, Harcourt, 1990.

—. Život bez smokingu. Československý spisovatel, 1986.

—. Kluby Poezie. Mladá fronta, 1981.

Jankovič, Milan. “Čas Př́liš hlučné samoty.” Cesty za smyslem literárního díla, Karolinum, 2005, pp. 227-254.

_ . "Epilogue: Hlučná samota Bohumila Hrabala." Př́liš hlučná samota, by Bohumil Hrabal, Odeon, 1989, pp. 120-134.

King, Jeannette. Discourses of Ageing in Fiction and Feminism. Palgrave Macmillan, 2012.

Kolář, Jiří. Křestný list. Odeon, 1992 [1941].

Kotyk, Petr et al. Hlučná Samota: 1914/2014 - Sto let Bohumila Hrabala. Mladá fronta, 2014.

Landy, Joshua. Philosophy as Fiction: Self, Deception, and Knowledge in Proust. Oxford UP, 2004.

Lively, Penelope. Moon Tiger. Grove, 1987.

McKim, A. Elizabeth, and William L. Randall. "From Psychology to Poetics: Aging as a Literary Process." Journal of Aging, Humanities, and the Arts, vol. 1, no. 3-4, 2007, pp. 147-158.

Novalis (Friedrich von Hardenberg). Philosophical Writings. Translated and edited by Margaret Mahony Stoljar, SUNY P., 1997.

Pelán, Jiří. "Bohumil Hrabal v sedmdesátých letech." Spisy, vol. 3, by Bohumil Hrabal, edited by Václav Kadlec and Jiří Pelán, Mladá fronta, 2015, pp. 7-21.

__. "Quijotismus v Hrabalovi." Kapitoly z francouzské, italské a české literatury, Karolinum, 2007, pp. 467-472.

Phillips, Adam. Unforbidden Pleasures. Farrar, Straus and Giroux, 2015.

Pytlík, Radko. A neuvěritelné se stalo skutkem: O Bohumilu Hrabalovi. Emporium, 1997.

Quinodoz, Danielle. Growing Old: A Journey of Self-Discovery. Translated by David Alcorn, Routledge, 2010.

Randall, William L., and A. Elizabeth McKim. Reading Our Lives: The Poetics of Growing Old. Oxford UP, 2008.

Roth, Susanna. Postface. Une trop bruyante solitude, by Bohumil Hrabal, translated by Max Keller, Robert Laffont, 1983, pp. 129-132.

Schreiberová, Jarmila, editor. Bohumil Hrabal-Jǐri Kolářr: pruseč́ky, paralely i mimoběžky života a díla. Památník národního písemnictví, 2014.

Slejška, Dragoslav. "Hodnoty, Hrabal a Haňt'a.” Hrabaliana: sborník pracík 75. narozeninám Bohumila Hrabala, edited by Milan Jankovič and Josef Zumr, Prostor, 1990, pp. 95-104.

Small, Helen. The Long Life. Oxford UP, 2007.

Stolz-Hladká, Zuzana. "Bohumil Hrabal and the Corporeality of the World." Bohumil Hrabal: Papers from a Symposium, edited by David Short, School of Slavonic and East European Studies Occasional Papers, 2004, pp. 35-49.

Thomas, Alfred. Prague Palimpsest: Writing, Memory, and the City. Chicago UP, 2010.

Tzu, Lao. Tao Te Ching. Translated by Charles Muller, Introduction and Notes by Yi-Ping Ong, Barnes and Noble, 2005.

—. Tao Te Ching. Translated by D. C. Lau, Penguin, 1963.

Winkel, Heike. "The Beauty of Compacting Human Heads. Metaphors of Writing and the History of Book Destruction in Bohumil Hrabal's Too Loud a Solitude." Slovo a smysl, no. 24, 2015, pp. 180-195. 